\title{
Stunting Risk Factors In Children Under 5 Years Old In Indonesian Border Regions (North Kalimantan- Malaysia)
}

\author{
Ika Yulianti ${ }^{1 *}$, Nurasmi², Rahmi Padlilah ${ }^{3}$ \\ 1,2,3 Department of Midwifery, Faculty of Health Sciences, University of Borneo Tarakan, \\ Indonesia \\ * Corresponding author: \\ Email: ikatamaevan@gmail.com
}

\begin{abstract}
.
Stunting in children becomes a health problem that gets priority and must be addressed immediately, especially at the border. Stunted development, decreased cognitive function and immune function as well as the risk of diabetes mellitus, coronary heart disease, hypertension and obesity are the effects of stunting. The aim of the study was to systematically find out the risk factors for stunting on the North Kalimantan-Malaysia border. Methods of using systematic review. Research from as many as 454 articles later in PRISMA analysis into 10 articles came from databases such as Pubmed, Science Direct, google scoolar. The results showed that the risk factors for stunting are Birth Length, Exclusive breast milk companion food, exclusive breastfeeding, family opinion, maternal factors namely age, attitude, occupation, knowledge, education and height..
\end{abstract}

Keywords: Risk factors, stunting, border areas

\section{INTRODUCTION}

Sustainable Development Goals (SDGs) one of the objectives in the field of health sector mention the target of public nutrition, namely in 2030, put an end to all ben - tuk malnutrition, including achieving the target inter - na - ternational 2025 for reduction of stunting and wasting among children under five, the program reduction of stunting dilalukan globally Government membe - ri - right attention to stunting in children under the age of 2-3 years one through the national nutrition and internal movement - sional ie movement Scaling Up Nutriti on (SUN) with pemeratan system up to the border area [1]. Genesis stun - ting around the world are taken into - kirakan about $26 \%$ of children under five.

[2] in Indonesia worth, in 2013 approximately 37.2\% of children under five suffer stun - ting and fell to $30.8 \%$ with a prevalence of stun - ting fifth-largest. Stunting will have an impact on the level of intelligence and more vulnerable terha and inco - kit and to increase to - mis - ki - nan and widening inequality [3].Stunting is influenced by factors pen - in - tance low maternal, height $<145 \mathrm{~cm}$, age $<20$ years and 
$\geq 35$ years, knowledge and attitudes that are less negative mothers. [4] me - his - Takan that the educational level phon - babkan stunting due to lack to - mam - pared with the mother in receiving infor - masi about nutrition, Another factor is the high body of the mother $<150 \mathrm{~cm}$ for the condition pa - to - logy (such as hormone deficiency partum harbor) to enlarge luxury suites opportunities - ris - kan gene so that children grow up to be stunting [5].

[6] describes the sump - wa lack of knowledge of women in the peri - la - ku health and hygiene lingku - ngan experienc - nga - the spirit of the occurrence of infectious diseases as well as working mothers at risk Memi - li - ki child stunting because of a lack of maternal attention to the vi - tu - han child nutrition. [7] also explained that stunting was affected by giving complementary feeding too early. Research related to stunting continues to be improved by using varied research designs, however the low level of research in border areas makes researchers interested in conducting research on stunting in border areas. The researcher aims to conduct a systematic review research with the PRISMA approach.Based on this, researchers are interested in research related to "Risk Factors for Stunting in Toddlers Age Under Five Years in Indonesian Border Areas".

\section{METHODS}

This systematic review was carried out in accordance with the Preferred Reporting Items for Systematic Reviews or Meta-Analyses (PRISMA) statement. Systematic database searches were carried out from September - October 2021. The databases included PubMed, google scholar and Science Direct. The keywords for this review included: ""stunting" AND "risk factors" AND "Children Under Five" AND (border area or rural region) AND (North Kalimantan or Malaysia)".

Inclusion criteria: retrospective, observational, cross-sectional, review, systematic review, and meta-analysis. The variable studied was stunting. Subjects are toddlers under the age of 6 years. Full paper published in English or Indonesian. Exclusion Criteria: Full paper in Chinese, Spanish, Arabic, Russian, and French. The risk factors for stunting are birth length, complementary feeding, exclusive breastfeeding, family opinion, maternal factors, namely age, attitude, occupation, knowledge, education and height. 


\section{RESULT AND DISCUSSION}

After the search process through the database obtained the following results:

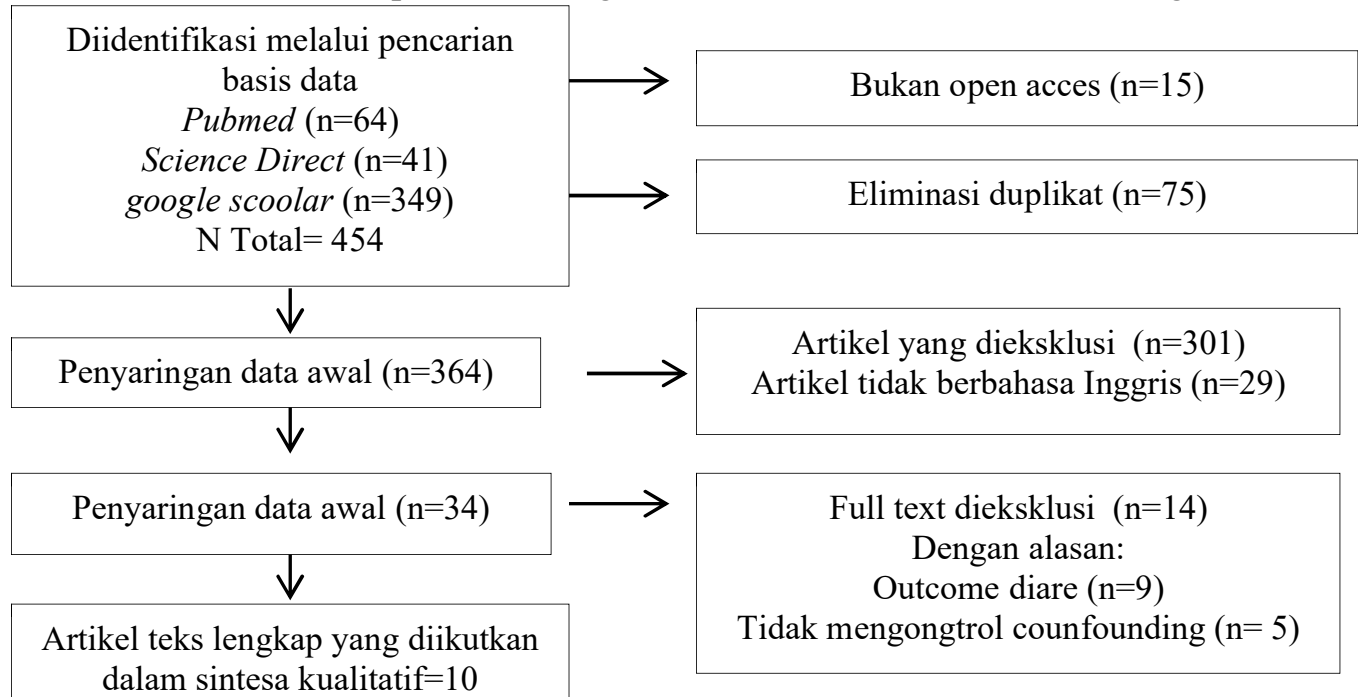

Fig 1.Systematic Review Flow

Table 1. Research Journal

\begin{tabular}{|c|c|c|c|}
\hline $\begin{array}{c}\text { Author } \\
\text { and year }\end{array}$ & $\begin{array}{c}\text { Number of subjects and research } \\
\text { locations }\end{array}$ & $\begin{array}{l}\text { stunting } \\
\text { category }\end{array}$ & Scale used \\
\hline $\begin{array}{l}\text { Sartika et } \\
\text { al. }(2021)\end{array}$ & 559 (Sambas District) & $\begin{array}{c}\text { Underweight } \\
\text { Stunting } \\
\text { wasting }\end{array}$ & ordinal \\
\hline $\begin{array}{l}\text { Titaley et } \\
\text { al. }(2019)\end{array}$ & $\begin{array}{c}24567 \text { (borders of NTT, NTB, Java, Bali, } \\
\text { Sumatra, Kalimantan }\end{array}$ & $\begin{array}{l}\text { Stunting } \\
\text { Stunting }\end{array}$ & ordinal \\
\hline $\begin{array}{c}\text { Indriyani } \\
\text { et } \\
\text { al.(2018) }\end{array}$ & 200 (North Kalimantan Border) & $\begin{array}{l}\text { Stunting } \\
\text { Normal }\end{array}$ & ordinal \\
\hline $\begin{array}{l}\text { Sugiyanto } \\
\text { et } \\
\text { al. }(2019)\end{array}$ & 225 (North Kalimantan Border) & $\begin{array}{l}\text { Stunting } \\
\text { Normal }\end{array}$ & ordinal \\
\hline $\begin{array}{l}\text { Gunardi et } \\
\text { al. (2019) }\end{array}$ & 174 (Bahar) & $\begin{array}{l}\text { Underweight } \\
\text { Stunting } \\
\text { wasting }\end{array}$ & ordinal \\
\hline $\begin{array}{l}\text { Ilma et } \\
\text { al. }(2019)\end{array}$ & 200 (Kupang) & $\begin{array}{c}\text { Stunting } \\
\text { No Stunting }\end{array}$ & ordinal \\
\hline $\begin{array}{l}\text { Wong et } \\
\text { al. (2014) }\end{array}$ & 274 (malaysia) & $\begin{array}{c}\text { Stunting } \\
\text { No Stunting }\end{array}$ & ordinal \\
\hline $\begin{array}{l}\text { Wellina et } \\
\text { al. }(2016)\end{array}$ & 154 (Brebes) & $\begin{array}{l}\text { Stunting } \\
\text { Normal }\end{array}$ & ordinal \\
\hline $\begin{array}{c}\text { Malonda } \\
\text { et } \\
\text { al. }(2020)\end{array}$ & 52 (North Kalimantan Border) & $\begin{array}{l}\text { Stunting } \\
\text { Normal }\end{array}$ & ordinal \\
\hline
\end{tabular}




\begin{tabular}{cccc}
\hline $\begin{array}{c}\text { Candriasih } \\
\text { et }\end{array}$ & 35 (Sulawesi) & Very & ordinal \\
al. $(2021)$ & & Inhibited & \\
& & Stunting & \\
& & Normal & \\
\hline Sumantri & 1013 (South Sulawesi) & Stunting & ordinal \\
et & & Normal & \\
al. $(2016)$ & & & \\
\hline
\end{tabular}

Based on the 10 articles, it is known that the risk factors associated with stunting at the Indonesian border are as follows:

1. The effect of birth weight on the incidence of stunting in children aged 2-3 years

The results showed terda - pat pe - been influenced significantly between birth weight infants the incidence stun-ting. Birth weight is one Deter-Minan factors stunting [8]. Birth weight babies a low effect on pertumbu -han and perdevelopments slower infants compared with infants born with normal weight.Infants with birth weight baby is low in utero have me - nga - lami growth retardation intera ute - rin and can continue until age se - lan - jutnya after birth is with me - nga - lami growth and perkemba - ngan is slower than babies born to normal, and the impact the failure to grow and berkem - bang according to age. Based on studies dila - kukan show that weight birth babies have lower risk of 10:51 time to the occurrence of stunting banned - ding - kan the birth weight of normal particularly in the area are far from health facilities in this case related to the border region [9].

2. The effect of birth length on the incidence of stunting in children

\section{aged 2-3 years}

The results showed terda - pat pe - been influenced significantly between pan which birth weight on the incidence of stun - ting. St un - ting reflect ketidakmam pared to achieve growth opti - mal caused by health status or suboptimal nutritional status [10]. Long body short of going air born - the impact on the child's height in early childhood and adulthood [11].

The length of a short birth weight had a risk 2.4 times to experience stunting at the age of 6-12 months compared de - ngan children who had normal birth body length [12] explains that the body length $\geq 48 \mathrm{~cm}$ had 0.90 times the risk of not experiencing stunting banned - dingkan with birth length $<48 \mathrm{~cm}$. Thus, early detection efforts are needed, one of which is through routine ANC checks, but the lack of health service facilities, especially in border areas, especially in developing countries, makes it difficult to avoid, so more concrete efforts are needed to reduce stunting at the border.

3. Effect of breastfeeding against crimes - dian stunting in children aged 2-3 years

The results showed terda - pat pe-been influenced significantly between breastfeeding on the incidence of stunting. The provision of breastfeeding that are 
timely Meru-feed one of the factors that mempe-nga-Ruhi incidence of stunting. [12] explains that stunting affected by pembe - rian breastfeeding too early (babies less than 6 months) as well as the occurrence of infectious diseases (diarrhea), the percentage of events in the associate also with the lack of health facilities and drinking water facilities that affect the incidence of stunting in particular in border area. Giving food and drinks other than breast milk to infants aged 0-6 months causes the baby to experience digestive disorders, one of which is diarrhea and if the handling is not good it can lead to stunting in children. According to [13] explained that the provision of breastfeeding timely decrease the incidence of stunting, the provision of breastfeeding with mem - be - offered are zinc supplements have kemung-kinan 1.89 to increase the weight ba-and seen from the $z$ score dibandingkan with those not given the supplement.

4. The effect of exclusive breastfeeding on the incidence of stunting in children aged 2-3 years

The results showed terda - pat pe - been influenced significantly between estab - be - rian exclusive breastfeeding on the incidence of stun - ting. Growth failure after la - hir, as a reflection of breastfeeding ex - klusif less precise so phon - chapter kan stunting [10] . Efforts to reduce the incidence of stunting there - was to optimize the exclusive breastfeeding for 6 months. Exclusive breastfeeding is appropriate to provide protection terha - dap gastrointestinal infection which can phon - babkan bears a depletion of nutrients -babkan stunting [7]. [9] explains that exclusive breastfeeding to me-nu-runkan incidence of stunting that has the possibility of 0:23 times not terja - are conducive stunting compared to de - ngan not granted exclusive breastfeeding.

5. The effect of family income on the incidence of stunting in children aged 2-3 years through infant birth weight

The results showed that terda - pat a significant influence between penda - ents family on the incidence of stunting. Family income during pregnancy meninges katkan development in children with birth weight so decreased-kan incidence of stunting [3]. Families with high incomes have the ability to meet nutritional needs and choose good health services for children so that it will prevent the occurrence of infectious diseases that cause stunting . [13] also Menje - laskan that family income mem - pu - nyai important role in giving effect to a standard of living berorien - tation on health and welfare thus decreasing the likelihood of stun - ting .

\section{The influence of maternal age on crimes - dian stunting in children aged 2-3 years through the birth weight infants}

The results showed that there was a significant effect between maternal age during pregnancy on the incidence of stunting. According to [3], pregnant women aged over 35 years have a 2.74 times risk of giving birth to stunted children compared to mothers who give birth at the age of 25-35 years. [6] also become clear - right that pregnancy by age Keha - mi - lan past 20-35 years is safe because of the maturity of 
organs of reproduction and mentally to go through pregnancy and childbirth. Research conducted by [7] showed that children of mothers aged less than 19 years of the meninges - katkan risk for impaired growth that was short at the age of 2 years by 30 $40 \%$.

\section{The effect of mother's attitude on the incidence of stunting in} children aged 2-3 years through complementary feeding and exclusive breastfeeding

The results showed that terda - pat a significant effect on the incidence of maternal attitude stunting through breastfeeding and exclusive breastfeeding. According to [9] a positive attitude is one of the determinants of factors that influence exclusive breastfeeding. The research [11] me - nun - has put forward correlation with behavioral attitude of exclusive breastfeeding. Mothers with a positive attitude towards exclusive breastfeeding has to - mung - duction to buy souvenirs offered are exclusive breastfeeding than mothers with a negative attitude.

Breastfeeding exclusively can reduce stunting kare - na calcium content of milk is more effi-ciently absorbed. Indi-kator to consider in pembe-rian breastfeeding is the age of giving breastfeeding, types of breastfeeding, the frequency of breastfeeding, the portion of the provision of breastfeeding and the provision of breastfeeding in the early stages [14] . [4] Menje - laskan that attitude positive mothers ter - toward breastfeeding mem - given the role of pen - ting to peme $\mathrm{nu}$ - han infant nutrition and able to stimulate eating skills and self-confidence in the baby.

8. The effect of work on the incidence of stunting in children aged 2-3 years through family income

The results showed terda-pat pe - been influenced significantly between Peker - jaan mother on the incidence of stunting . [1] men - je - laskan that women who berpen - in - tance height usually busy with aktivi - bag outside the home because of work, but with the work that is owned mother is able meninges - katkan revenue out - ga se - hing - ga to - cen - roar for meme - nu - hi the family's food needs are better. The higher the family income, the mother is likely to switch to formula so that mothers no longer membe - offered are breastfeeding their babies [11] . [4] become clear - right that mothers who work outside the home can phon - babkan children less maintained that parenting would be affected and the fulfillment of the vi - god child nutrition so as meninges - katkan possibility of stunting .

9. The effect of knowledge on the incidence of stunting in children aged 2-3 years through attitudes

The results showed terda - pat pe - been influenced significantly between pe bold - of knowledge of mothers on the incidence of stunting . [14] explains that the negative attitudes related to food experienc mother - been influenced against the actions and behavior of the negative mother so the impact on child nutrition issues one of which is stunting. According to [4] knowl - knowledge of poor maternal nutrition 
dipenga - Ruhi by a lack of care about nutrition, so it will have an impact on the tum buh flower toddler.

Based ha - sil research diketa - hui that there pe - been influenced by lang sung long birth weight, birth weight infants, exclusive breastfeeding and complementary feeding as well as a gyro - sung affected by the pen-acquired to family has, maternal age, mother's attitude, height mother, employment, education and pengeta - huan.

10. The effect of education on the incidence of stunting in children aged 2-3 years through work and knowledge

The results showed terda - pat pe - been influenced significantly between early pension-tance to the incidence of stunting through Peker-jaan and knowledge. [5] become clear-right that higher education related to maternal employment outside the home so that the lowering of exclusive breastfeeding and increase the risk of stunting .

According to [12] mothers who work at home can apply more time to buy souvenirs - offered are the best parenting and the mother can focus on parenting and experienc - been influenced the growth and development of children better. Mothers who work outside the home had 5.38 times the risk of stunting compared to de - ngan housewife. Mother's education is useful in receiving information about nutrition and health problems from outside so that mothers are able to choose and serve food for the family and reduce the incidence of stunting [14]. Research conducted by [13] show that the pen - upbringing low ( $<\mathrm{SMA})$ has a 1:28 times the risk of stunting banned dingkan with children whose mothers berpen - educated high.

11. The influence of maternal height terha-dap incidence of stunting among children aged 2-3 years through the body length of birth

The results showed that terda - pat significant influence of maternal height on the incidence of stunting among children aged 2-3 years. One of the determinants of factors that influence birth length is maternal height. [12] According to [4] long high birth weight influenced by maternal body because it is based on aspects Biolo - gis attributed to internal factors are the factors of the mother (a genetic factor) that is associated with the incidence of stunting .

The results of this study are in line with the research conducted by [7] showed that mothers with maternal height $<150 \mathrm{~cm}$ had a 1.39 times risk of having a child with a birth length $<48 \mathrm{~cm}$ thereby increasing the risk of stunting. Based on the results peneitian can - concluded that there is a direct influence long birth weight, birth weight infants, exclusive breastfeeding and complementary feeding as well as directly dipe - influenced by family income, maternal age, mother's attitude, height mother, work, pen - upbringing and knowledge. 


\section{CONCLUSION}

The results showed that the risk factors for stunting were birth length, complementary feeding, exclusive breastfeeding, family opinion, maternal factors, namely age, attitude, occupation, knowledge, education and height. Thus, it is hoped that it can be used as a reference source and as material for health promotion in the context of efforts to reduce the incidence of stunting at the Indonesian border.

\section{REFERENCES}

[1] A Singh, AK Upadhyay, K Kumar. Birth Size, Stunting and Recovery from Stunting in Andhra Pradesh, India: Evidence from the Young Lives Study. Maternal and Child Health Journal. Springer US, 2016. DOI: 10.1007/s1099501621328

[2] EP Prawirohartono, DS Nurdiati, M Hakimi. Prognostic Factors at Birth for Stunting at 24 Months of age in Rural Indonesia. Paediatr Indonesia, 56(1), 2016, pp. 48-56.

[3] V Khanal, K Sauer, Y Zhao, R Black, S Cousens, H Johnson. Determinants of Complementary Feeding Practices among Nepalese Children Aged 6-23 Months: Findings from Demographic and Health Survey 2011. BMC Pediatrists, 13(1), 2013, pp. 131.

[4] MEG Armstrong, MI Lambert, EV Lambert. Secular Trends in the Prevalence of Stunting, Overweight and Obesity among South African Children (1994-2004). European Journal of Clinical Nutrition, 65(7), 2011, pp. 835-840. DOI.10.1038/ejen.2011.46.

[5] CA Onyango, SO Ochanda, MA Mwasaru, JK Ochieng, FM Mathooko, JN Kinyuru. Effects of Malting and Fermentation on Anti-Nutrient Reduction and Protein Digestibility of Red Sorghum, White Sorghum and Pearl Millet. Journal of Food Research, 2(1), 2013. DOI: 10.5539/jfr.v2n1p41.

[6] TM Huda, A Hayes, SE Arifeen, MJ Dibley. Social Determinants of Inequalities in Child Undernutrition in Bangladesh: a Decomposition Analysis. Matern Child Nutr, 14(1), 2017, Pp. 12440. DOI. https://doi.org/10.1111/mcn.12440 .

[7] R Akram, M Sultana, N Ali, N Sheikh, RA Sarker. Prevalence and Determinants of Stunting Among Preschool Children and Its Urban-Rural Disparities in Bangladesh. Food and Nutrition Bulletin, 39(2), 2018, pp. 1-15. DOI: 10.1177/0379572118794770

[8] LS Rahayu. Effect of LBW (Low Birth Weight) and Exclusive Breastfeeding on Changes in Stunting Status in Toddlers in Tangerang City and Regency, Banten Province. The Role of Public Health in Achieving the MDG's in Indonesia, 2011, pp.160-169. DOI. http://journal.unsil.ac.id/jurnal/prosiding/9/9leni_9 pdf.pdf..

[9] JPD Barker, O Clive, JF Tom, LT Kent, K Eero, GE Johan. Foetal and Childhood Growth and Asthma In Adult Life. Published by John Wiley \& Sons Ltd, 102, 2013, pp. 732-738. DOI. https://doi.org/10.1111/apa.12257

[10] A Rahmadi. Relationship between birth weight and length with the incidence of stunting in children 12-59 months in Lampung Province. Journal of Nursing, XII(2), 2016, http://www.ugm.ac.id/accessed

[11] AM Dorélien. Effects of Birth Month on Child Health and Survival in Sub-Saharan Africa. Biodemography Soc Biol, 
61(2), 2016, pp. 209-230. DOI. 10.1080/19485565.2015.1032399.

[12] LS Rahayu. Effect of LBW (Low Birth Weight) and Exclusive Breastfeeding on Changes in Stunting Status in Toddlers in Tangerang City and Regency, Banten Province. The Role of Public Health in Achieving the MDG's in Indonesia, 2011, pp. 160-169. DOI. http://journal.unsil.ac.id/jurnal/prosiding/9/9leni_9 pdf.pdf.

[13] V Uwiringiyimana, C Marga, S Amer, A Veldkamp. Predictors of Stunting with Particular Focus on Complementary Feeding Practices: a Cross-Sectional Study in the Northern Province of Rwanda. Nutrition, 60, 2019, pp. 11-18. DOI. doi:10.1016/j.nut.2018.07.016.

[14] Y Kamiya, M Nomura, H Ogino, K Yoshikawa, L Siengsounthone, P Xangsayarath. Mothers' Autonomy and Childhoodstunting: Evidence from Semi-Urbancommunities in Lao PDR. BMC Women's Health, 18, 2018, pp. 70. DOI. https://doi.org/10.1186/s12905-018-0567-3 . 